\title{
WATERMELON YIELD AND EFFICIENCY OF USE OF WATER AND NITROGEN $^{1}$
}

\author{
LAÉRCIO DA SILVA PEREIRA ${ }^{2}$, EVERALDO MOREIRA DA SILVA ${ }^{3}$, JOSÉ ORLANDO PIAUILINO FERREIRA ${ }^{4}$, \\ VINÍCIUS LEMOS GUERRA SANTOS ${ }^{5}$, CARLOS JOSÉ GONÇALVES DE SOUZA LIMA ${ }^{6 *}$, GABRIEL BARBOSA \\ DA SILVA JÚNIOR ${ }^{7}$
}

\begin{abstract}
The evaluation of the yield of crops and their efficiency of use of water and nitrogen is essential to optimize the management of production factors. The objective of this study is to evaluate the effect of irrigation regimes and nitrogen doses in fertigation on fruit yield and efficiency of use of water and nitrogen by the Top Gun watermelon hybrid. The study was conducted in Bom Jesus, Piauí, Brazil, from August 4 to October 15, 2015. The study used a completed randomized block design with four repetitions, five irrigation depths $(110.17,156.86,221.16,268.87$, and $317.09 \mathrm{~mm})$, and five doses of nitrogen in fertigation $(0,50,100$, 150 , and $200 \mathrm{~kg} \mathrm{ha}^{-1}$ applied as urea). Fruit yield and water use efficiency were not affected by nitrogen doses; however, there was a significant interaction of the factors for the efficiency of nitrogen use. The highest yield $\left(39,549.45 \mathrm{~kg} \mathrm{ha}^{-1}\right)$ was obtained using $233.48 \mathrm{~mm}$ of water during the growth cycle. The water depth that promoted the maximum efficiency of water use was $110.42 \mathrm{~mm}$, and nitrogen use was most efficient using $232.21 \mathrm{~mm}$ of water and $50 \mathrm{~kg} \mathrm{ha}^{-1}$ of nitrogen.
\end{abstract}

Keywords: Citrullus lanatus. Fertigation. Irrigation.

\section{PRODUTIVIDADE E EFICIÊNCIA DE USO DA ÁGUA E NITROGÊNIO PELA MELANCIEIRA}

RESUMO - A avaliação da produtividade das culturas e suas eficiências de uso da água e de fertilizantes, constituem-se valiosas informações a serem consideradas, visando a otimização no manejo dos fatores de produção. Objetivou-se avaliar o efeito de lâminas de irrigação e doses de nitrogênio, em fertirrigação, sobre a produtividade e as eficiências de uso da água e nitrogênio pela melancieira, híbrido Top Gun. O experimento foi conduzido na cidade de Bom Jesus - PI, durante o período de 4 de agosto a 15 de outubro de 2015. O delineamento experimental adotado foi o de blocos ao acaso e em faixas, com quatro repetições, sendo os tratamentos constituídos por cinco lâminas de irrigação $(110,17 ; 156,86 ; 221,16 ; 268,87$ e 317,09 mm) e cinco doses de nitrogênio em fertirrigação $\left(0,50,100,150\right.$ e $200 \mathrm{~kg} \mathrm{ha}^{-1}$ aplicados na forma de ureia). A produtividade e a eficiência de uso da água não foram influenciadas pelas doses de nitrogênio; no entanto, houve interação significativa dos fatores para a eficiência de uso do nitrogênio. A maior produtividade $\left(39.549,45 \mathrm{~kg} \mathrm{ha}^{-1}\right)$ foi obtida com 233,48 mm de água no ciclo. A lâmina de irrigação que promoveu a máxima eficiência de uso da água foi de $110,42 \mathrm{~mm}$ e a melhor eficiência de uso do nitrogênio foi obtida com 232,21 $\mathrm{mm}$ de água e $50 \mathrm{~kg} \mathrm{ha}^{-1}$ de nitrogênio.

Palavras- chave: Citrullus lanatus. Fertirrigação. Irrigação.

\footnotetext{
${ }^{*}$ Corresponding author

${ }^{1}$ Received for publication in $04 / 23 / 2018$; accepted in $04 / 03 / 2019$.

Paper extracted from the master dissertation of the first author.

${ }^{2}$ Universidade Estadual Paulista “Júlio de Mesquita Filho", Botucatu, SP, Brazil; abreu91@hotmail.com - ORCID: 0000-0001-8929-5084.

${ }^{3}$ Department of Engineering, Universidade Federal do Piauí, Bom Jesus, PI, Brazil; everaldo@ufpi.edu.br - ORCID: 0000-0003-08883365.

${ }^{4}$ Technical College of Bom Jesus, Universidade Federal do Piauí, Bom Jesus, PI, Brazil; orlando@ufpi.edu.br - ORCID: 0000-0002-49707942 .

${ }^{5}$ Universidade Federal do Piauí, Bom Jesus, PI, Brazil; viniciuslgs@hotmail.com - ORCID: 0000-0003-3244-5461.

${ }^{6}$ Department of Agricultural Engineering and Soil Science, Universidade Federal do Piauí, Teresina, PI, Brazil; carloslima@ufpi.edu.br ORCID: 0000-0003-0390-4323.

${ }_{7}^{7}$ Department of Plant Science, Universidade Federal do Piauí, Teresina, PI, Brazil; gabrielbarbosa@ufpi.edu.br - ORCID: 0000-0002-40559867.
} 


\section{INTRODUCTION}

The use of water and nitrogen is essential to increase crop yield. However, these resources should be used with caution because the lack or excess of these resources strongly affects agricultural yield. The development of agricultural activities depends on productive and economic parameters as well as the efficiency in the use of resources, especially water and nitrogen.

Water use efficiency (WUE) affects crop yield according to the irrigation depth applied during the growth cycle whereas nitrogen use efficiency (NUE) can improve crop yield as the nitrogen levels are increased. Understanding these efficiencies and their implication in the productive responses of crops is fundamental to optimize the use of production factors (MONTEIRO et al., 2008).

It is necessary to optimize production factors, especially water use, and prioritize production per cubic meter instead of production per unit area (MONTEIRO et al., 2008). Melo et al. (2010) analyzed a watermelon culture under different irrigation regimes and observed that a water depth of $266 \mathrm{~mm}$ promoted a maximum fruit yield of 52,400 $\mathrm{kg} \mathrm{ha}^{-1}$ and WUE of $19.6 \mathrm{~kg} \mathrm{~m}^{-3}$, and the latter was lower than the value obtained at a water depth of $204.67 \mathrm{~mm}\left(23.2 \mathrm{~kg} \mathrm{~m}^{-3}\right)$.

Morais et al. (2008) evaluated the response of watermelon at different water and nitrogen levels and found that a water depth of $205 \mathrm{~mm}$ and nitrogen concentration of $249 \mathrm{~kg} \mathrm{ha}^{-1}$ promoted the highest WUE, corresponding to 24.21 and $22.10 \mathrm{~kg} \mathrm{~m}^{-3}$, respectively. These results demonstrate that the efficient use of water and nitrogen promote less waste, improve the rational use of production factors, and increase the profits of irrigated crops (ANDRADE JÚNIOR et al., 2006; FERREIRA; PAVANI; BASTOS, 2013).

Monteiro et al. (2008) studied melon plants, another Cucurbitaceae, and observed that WUE decreased as the water depth increased, and WUE was highest using $232.7 \mathrm{~mm}$ of water. However, these authors observed that the water depths and nitrogen doses, as well as the interaction between these two factors, did not affect NUE by the crop.

Therefore, further studies are needed to optimize WUE and NUE by crops, avoiding the waste of water and fertilizers. The objective of this study is to evaluate the effect of different water depths and nitrogen doses in fertigation on fruit yield, and WUE and NUE in Bom Jesus, Piauí, in the Amazon region of Brazil.

\section{MATERIAL AND METHODS}

The study was conducted from August to October 2015 at Sitio São Luiz in the municipality of Bom Jesus (latitude, 905'20.4" S; longitude, 44'20'55.1" W; altitude, $283 \mathrm{~m}$ ), Piauí, Brazil, in an area of $2,500 \mathrm{~m}^{2}$. The climate of the region is classified as dry subhumid, with a mean annual rainfall of 900-1200 $\mathrm{mm}$ and mean temperature of $26.5^{\circ} \mathrm{C}$, although temperatures of $40{ }^{\circ} \mathrm{C}$ are common throughout the year (VIANA et al., 2002).

The soil of the study area is classified as Flossic Neosol, with frank sandy and sandy soils at a depth of $0.0-0.20$ and $0.20-0.40 \mathrm{~m}$, respectively. The soil was prepared by plowing and harrowing. Liming was calculated using the soil base saturation method and was performed to increase base saturation to $60 \%$ and correct acidity. The limestone used was dolomite filler with a total relative neutralizing power of $94 \%$ and was applied by broadcasting at a concentration of $1.05 \mathrm{Mg} \mathrm{ha}^{-1}$ and incorporated at a depth of $0.20 \mathrm{~m}$. The soil presented the following chemical, physical, and water characteristics after 30 days of correction (Table 1).

The study used a completed randomized block design with four repetitions, with the treatments corresponding to five irrigation depths $(50,75,100,125$, and $150 \%$ of the reference evapotranspiration) and five nitrogen doses $(0,50$, 100,150 , and $200 \mathrm{~kg} \mathrm{ha}^{-1}$ ) in the form of urea in fertigation in a watermelon crop. Each plot included margins and a useful area of $20 \mathrm{~m}^{2}$ and contained five plants.

Seeds of the F1 Top Gun hybrid were chosen because of its high commercial value and lack of technical information in the region. Planting was carried out by direct seeding in pits (dimensions of $0.3 \times 0.3 \times 0.3 \mathrm{~m})$, with one seed per pit at a spacing of $2.00 \times 2.00 \mathrm{~m}$. 
L. S. PEREIRA et al.

Table 1. Chemical, physical, and water characteristics of the soil in the municipality of Bom Jesus, Piauí, Brazil.

\begin{tabular}{|c|c|c|}
\hline Characteristics & \multicolumn{2}{|c|}{ Soil layer (m) } \\
\hline Chemical & $0.0-0.20$ & $0.20-0.40$ \\
\hline $\mathrm{pH}\left(\mathrm{CaCl}_{2}\right)$ & 5.3 & 5.0 \\
\hline $\mathrm{P}$ (Mehlich) $\mathrm{mg} \mathrm{dm}^{-3}$ & 4.3 & 2.4 \\
\hline $\mathrm{K}\left(\mathrm{mg} \mathrm{dm} \mathrm{m}^{-3}\right)$ & 53.0 & 30.0 \\
\hline $\mathrm{Ca}\left(\mathrm{cmol}_{\mathrm{c}} \mathrm{dm}^{-3}\right)$ & 2.1 & 1.5 \\
\hline $\mathrm{Mg}\left(\mathrm{cmol}_{\mathrm{c}} \mathrm{dm}^{-3}\right)$ & 1.2 & 0.9 \\
\hline $\mathrm{S}\left(\mathrm{mg} \mathrm{dm} \mathrm{m}^{-3}\right)$ & 3.4 & 4.0 \\
\hline $\mathrm{Al}$ (exchangeable) $\left(\mathrm{cmol}_{\mathrm{c}} \mathrm{dm}^{-3}\right)$ & 0.2 & 0.3 \\
\hline $\mathrm{Na}\left(\mathrm{mg} \mathrm{dm}^{-3}\right)$ & 6.0 & 5.0 \\
\hline $\mathrm{OM}\left(\mathrm{g} \mathrm{dm}^{-3}\right)$ & 11.0 & 7.0 \\
\hline \multicolumn{3}{|l|}{ Physical } \\
\hline Coarse sand $\left(\mathrm{g} \mathrm{kg}^{-1}\right)$ & 638.89 & 668.72 \\
\hline Fine sand $\left(\mathrm{g} \mathrm{kg}^{-1}\right)$ & 260.65 & 240.55 \\
\hline Silt $\left(\mathrm{g} \mathrm{kg}^{-1}\right)$ & 40.20 & 30.13 \\
\hline Clay $\left(\mathrm{g} \mathrm{kg}^{-1}\right)$ & 60.26 & 60.60 \\
\hline Particle density $\left(\mathrm{g} \mathrm{cm}^{-3}\right)$ & 2.86 & 2.70 \\
\hline Soil density $\left(\mathrm{g} \mathrm{cm}^{-3}\right)$ & 1.61 & 1.64 \\
\hline \multicolumn{3}{|l|}{ Water } \\
\hline CC (\%) vol. & 16.9 & 13.2 \\
\hline PWP (\%) vol. & 4.0 & 4.5 \\
\hline
\end{tabular}

The doses of phosphorus $\left(120 \mathrm{~kg} \mathrm{ha}^{-1}\right.$ of single superphosphate) and potassium $\left(120 \mathrm{~kg} \mathrm{ha}^{-1}\right.$ of potassium chloride) were defined on the basis of soil chemical analysis (Table 1) according to the fertilization and liming recommendations for the state of Ceará (AQUINO et al., 1993). Phosphorus was applied in pits 10 days before planting, and potassium was applied according to the recommended application rate of this nutrient for this crop (Table 2).

Table 2. Application of nitrogen and potassium in watermelon crop.

\begin{tabular}{ccccccccc}
\hline Nutrient & \multicolumn{8}{c}{ Days after emergence (DAE) } \\
\hline & $1-13$ & $14-20$ & $21-27$ & $28-34$ & $35-41$ & $42-48$ & $49-55$ & Total \\
$\mathrm{K}_{2} \mathrm{O}$ & $5 \%$ & $5 \%$ & $8 \%$ & $16 \%$ & $18 \%$ & $23 \%$ & $25 \%$ & $100 \%$ \\
$\mathrm{~N}$ & $6 \%$ & $7 \%$ & $15 \%$ & $27 \%$ & $30 \%$ & $10 \%$ & $5 \%$ & $100 \%$ \\
\hline $\mathrm{N}\left(\mathrm{kg} \mathrm{ha}^{-1}\right)$ & \multicolumn{8}{c}{ Applied nitrogen (grams per plant) } \\
\hline 0 & 0.0 & 0.0 & 0.0 & 0.0 & 0.0 & 0.0 & 0.0 & 0 \\
50 & 1.2 & 1.4 & 3.0 & 5.4 & 6.0 & 2.0 & 1.0 & 20 \\
100 & 2.4 & 2.8 & 6.0 & 10.8 & 12.0 & 4.0 & 2.0 & 40 \\
150 & 3.6 & 4.2 & 9.0 & 16.2 & 18.0 & 6.0 & 3.0 & 60 \\
200 & 4.8 & 5.6 & 12.0 & 21.6 & 24.0 & 8.0 & 4.0 & 80 \\
\hline
\end{tabular}

The drip irrigation system consisted of a 3 horsepower pump with a flow rate of $8.5 \mathrm{~m}^{3} \mathrm{~h}^{-1}$, rotation of 3,500 rpm, and efficiency of $70 \%$; disc filter; inlet pipes, main pipes, and outlet pipes with a nominal diameter (ND) of $50 \mathrm{~mm}$ and length of 10, 50, and $3 \mathrm{~m}$, respectively. The secondary irrigation lines were made of PVC and had a ND of $32 \mathrm{~mm}$, from which lateral polyethylene lines of ND of $16 \mathrm{~mm}$ and length of $52 \mathrm{~m}$ were derived. The lateral lines contained IDROP online drippers distanced at $2.0 \mathrm{~m}$, flow rate of $8 \mathrm{~L} \mathrm{~h}^{-1}$, service pressure of $1 \mathrm{bar}$, and discharge coefficient of the pressure-flow curve " $x$ " equal to 0.5 .

The irrigation water came from a well with a depth of $150 \mathrm{~m}$ and was stored in a tank (width, 3.0 $\mathrm{m}$; length, $6.0 \mathrm{~m}$; depth, $2.0 \mathrm{~m}$ ) with a total capacity of $36 \mathrm{~m}^{3}$. The physical-chemical characteristics of the water were: $\mathrm{CE}, 30.22 \mu \mathrm{S} \mathrm{cm}^{-1} ; \mathrm{pH}, 5.1 ; \mathrm{Ca}, 1.0$, $\mathrm{Mg}, 0.6 ; \mathrm{K}, 0.4 ; \mathrm{Na}, 3.9 ; \mathrm{Cl}, 4.5 ; \mathrm{HCO}_{3}, 3.4$ (in mg L $\left.{ }^{-1}\right)$, and these qualities were considered excellent for irrigation purposes $\left(\mathrm{C}_{1} \mathrm{~S}_{1}\right)$. The applied water depths were calculated on the basis of the reference evapotranspiration (ETo) obtained by the method of Penman-Monteith and adapted by FAO (ALLEN et al., 1998).

The culture coefficient $(\mathrm{Kc})$ values obtained by Ferreira (2010) were 0.44 for phase I (1-12 days), 0.97 for phase II (13-32 days), 1.51 for phase III (33 -64 days), and 1.28 for phase IV (65-73 days). The coefficients of reduction $\left(\mathrm{K}_{\mathrm{L}}\right)$ by localized irrigation for each water depth were determined using the methodology of Keller and Bliesner (1990).

Daily climate data were obtained using an automatic meteorological station belonging to the National Institute of Meteorology (Instituto Nacional de Meteorologia-INMET) located at the Federal University of Piauí (Universidade Federal do PiauíUFPI) in Bom Jesus, Piauí, Brazil, campus Professor Cinobelina Elvas, located at a distance of $1000 \mathrm{~m}$ from the study site. This station contained sensors of 
air temperature, relative air humidity, solar radiation, and wind velocity, and these parameters were used to calculate the daily reference evapotranspiration (ETo). No rainfall occurred in the study period.

Wind speed was obtained at the height of 10 meters at the meteorological stations of INMET and was converted to a height of $2 \mathrm{~m}$ using the equation proposed by Allen et al. (1998). The variation in water depths was started at $20 \mathrm{DAE}$ and finished at 53 DAE. The climatic conditions in the study period are shown in Figure 1.
A

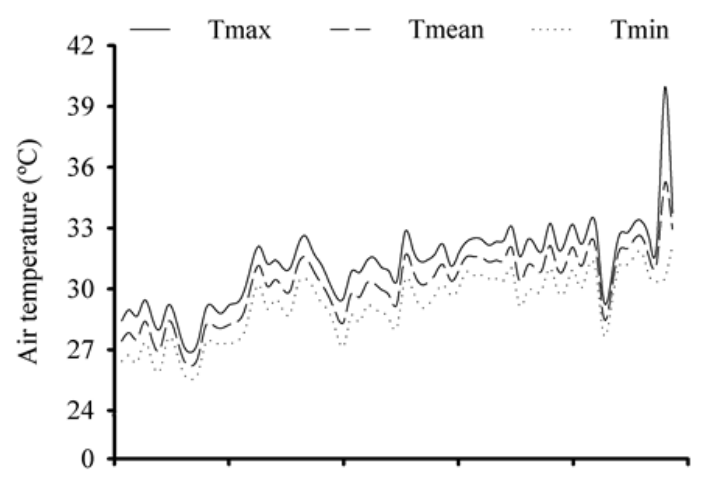

$\mathrm{C}$

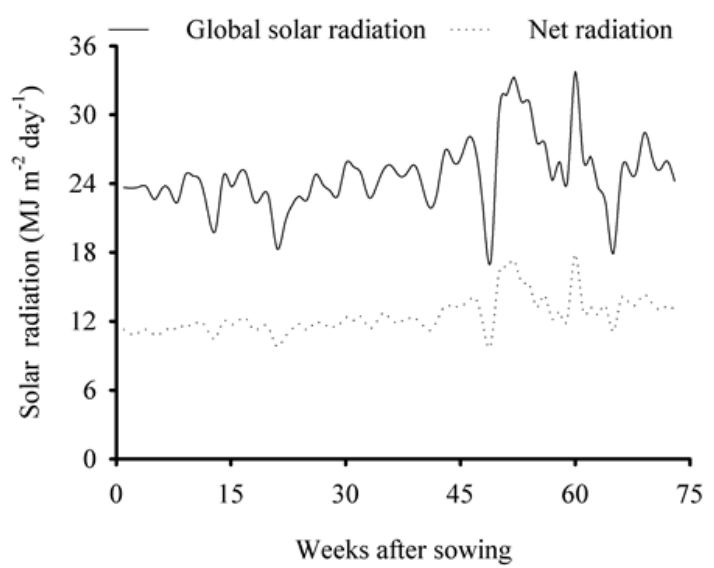

B

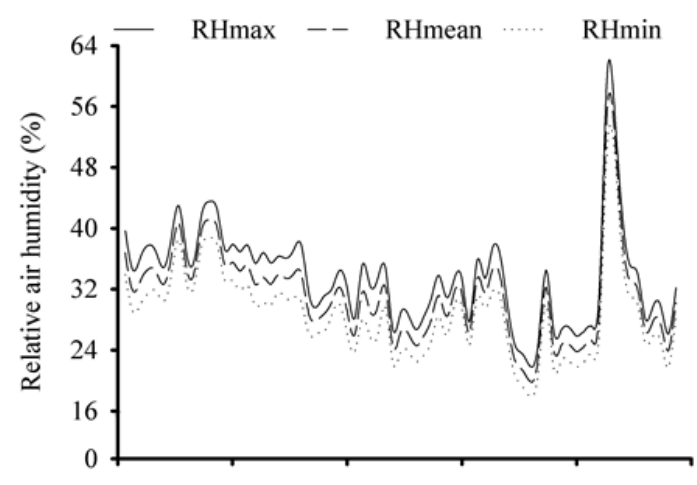

$\mathrm{D}$

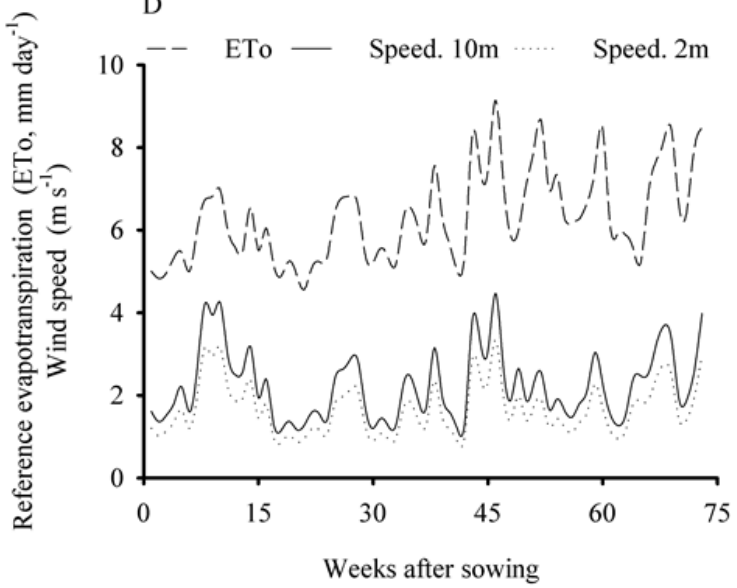

Figure 1. Mean, maximum, mean and minimum air temperature $\left({ }^{\circ} \mathrm{C}\right)(\mathrm{A})$; mean, maximum, and minimum relative air humidity (\%) (B); global solar radiation $\left(\mathrm{MJ} \mathrm{m}^{-2}\right.$ day $\left.^{-1}\right)$ and net radiation $(\mathrm{C})$; wind speed $\left(\mathrm{m} \mathrm{s}^{-1}\right)$ at a height of $2 \mathrm{~m}$ and 10 $\mathrm{m}$; and reference evapotranspiration $(\mathrm{mm})(\mathrm{D})$.

Nitrogen fertigation was applied daily and distributed during the growth cycle according to the method of Andrade Júnior et al. (2007) (Table 2). The nitrogen solutions were applied using a Venturitype injector at a rate of $80 \mathrm{~L} \mathrm{~h}^{-1}$ and working pressure of 1 bar.

Calcium $\left(6.0 \%, 79.8 \mathrm{~g} \mathrm{~L} \mathrm{~L}^{-1}\right)$, magnesium $\left(2.0 \%, 26.60 \mathrm{~g} \mathrm{~L}^{-1}\right)$, and boron $\left(1.0 \%, 13.33 \mathrm{~g} \mathrm{~L}^{-1}\right)$ were applied on the leaves using a Liqui-Plex source at 7-day intervals starting at day 33 after sowing, corresponding to the beginning of flowering, and ending at day 66 after sowing. Weed control was carried out by weeding, and pests and diseases were managed preventively with weekly applications of products recommended for watermelon culture.

The fruits were harvested at day 73 after sowing, and the harvest point was identified by observing the degree of dehydration of the tendril closest to the fruit and changes in fruit color from white to light yellow, especially in fruits in direct contact with the soil. The fruits classified as marketable were free of mechanical damage, diseases, spots, and deformations, and weighed at least $10 \mathrm{~kg}$. Marketable fruit yield (MFY) $\left(\mathrm{kg} \mathrm{ha-}{ }^{1}\right)$ was determined by weighing the fruits collected in each plot (ARAÚJO et al., 2011).

WUE $\left(\mathrm{kg} \mathrm{m}^{-3}\right)$ was calculated using the equation: WUE $=\mathrm{MFY} / 10$ ' $\mathrm{L}$, where MFY is the marketable fruit yield $\left(\mathrm{kg} \mathrm{ha}^{-1}\right)$, and $\mathrm{L}$ is the water depth (mm) (SOUSA et al., 2010). NUE $\left(\mathrm{kg} \mathrm{kg}^{-1}\right)$ was measured using the equation NUE $=\left(\mathrm{MFYF}^{+}-\right.$ $\mathrm{MFYF}^{-}$/Qa, where $\mathrm{MFYF}^{+}$is MFY with fertilizer $\left(\mathrm{kg} \mathrm{ha}^{-1}\right), \mathrm{FYF}^{-}$is MFY without fertilizer $\left(\mathrm{kg} \mathrm{ha}^{-1}\right)$, and $\mathrm{Qa}$ is the amount of nutrient applied to the crop ( $\left.\mathrm{kg} \mathrm{ha}^{-1}\right)$ (SILVA et al., 2014).

The data were subjected to analysis of variance at a level of significance of $5 \%$. Quantitative polynomial regression analysis was 
performed in cases of significant effects between the factors. Response surface analysis was used for the factors with a significant effect. The adopted models were chosen on the basis of the significance of the regression coefficients at a probability of $5 \%$ and the highest coefficient of determination $\left(\mathrm{R}^{2}\right)$.

\section{RESULTS AND DISCUSSION}

The water depths for $50,75,100,125$, and $150 \%$ of ETo corresponded to $110.17,156.86$,
$221.16,268.87$, and $317.09 \mathrm{~mm}$ for the growth cycle. The water depths in all treatments were lower than those recommended by Doorenbos and Kassan (1994) for watermelon crops (400-600 mm per growth cycle). These differences can be explained by the climatic variations in the cultivation sites as well as variations in sowing periods, soil characteristics, agricultural management, and growth cycles.

The analysis of MFY data indicated that there was a significant effect $(p<0.01)$ of the water depths. However, there was no significant effect $(p>0.05)$ of nitrogen doses and no significant interaction between these two sources of variation (Table 3).

Table 3. Analysis of variance of the marketable fruit yield of watermelon at different water depths and nitrogen doses used in fertigation.

\begin{tabular}{ccccc}
\hline Causes of variation & DF & F-value & $\begin{array}{c}\text { Probability } \\
>\mathrm{F}\end{array}$ & $\mathrm{R}^{2}$ \\
\hline Water depth (L) & 4 & 2644.48 & 0.00001 & \\
Linear regression & 1 & 3192.02 & 0.00010 & 0.3018 \\
Quadratic regression & 1 & 7285.74 & 0.00010 & 0.9905 \\
Nitrogen (N) & 4 & 0.01 & 0.99940 & \\
Linear regression & 1 & 0.01 & 0.92100 & 0.1576 \\
Quadratic regression & 1 & 0.03 & 0.85000 & 0.7337 \\
Interaction L $\times \mathrm{N}$ & 16 & 0.01 & 1.00000 & \\
\hline Overall mean & \multicolumn{5}{c}{$33,223.05 \mathrm{~kg} \mathrm{ha}^{-1}$} \\
\hline
\end{tabular}

The absence of response of the watermelon culture to the increase of $\mathrm{N}$ doses can be justified by the history of the use of the area, since applications of large amounts of $\mathrm{N}$, in total area, were carried out in previous crops, such as maize, beans and soybean, as well as due to the effect of $\mathrm{N}$ from the decomposition of organic matter. .

The mean MFY values were adjusted to the quadratic regression model by the water depths (Table 3). This type of adjustment was previously described by Morais et al. (2008) and Melo et al. (2010) for watermelon. The maximum MFY was $39,549.45 \mathrm{~kg} \mathrm{ha}^{-1}$ at an irrigation depth of 233.48 $\mathrm{mm}$ (Figure 2), with increments of $39.83 \%$ and
$20.44 \%$ when compared with the water depths of 110.17 and $317.09 \mathrm{~mm}$, respectively. These results can be explained by the adequate water supply in the soil, which increases the availability of nutrients, resulting in improved physiological conditions of the crop and higher production of photoassimilates. The availability of water in the soil directly affects stomatal opening and closure, which is primarily associated with light intensity and the state of hydration of the leaves. Therefore, the adequate functioning of stomata and the leaf area significantly affect plant productivity by regulating $\mathrm{CO}_{2}$ absorption and sunlight interception (COSTA, MARENCO, 2007).

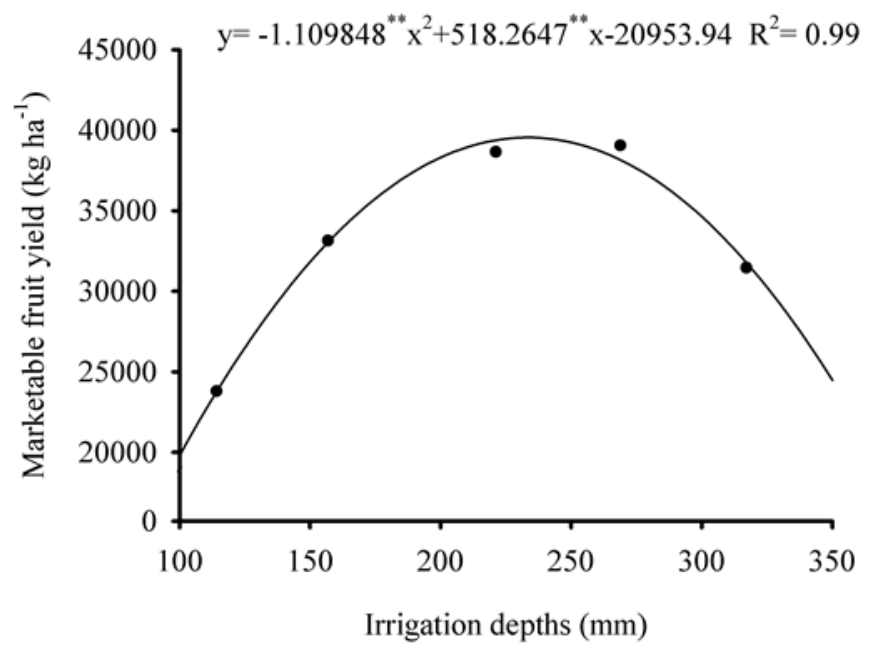

Figure 2. Regression analysis for the marketable fruit yield of watermelon fruits at different water depths. ** significant at a level of significance of $1 \%$ using Student's $t$-test. 
The MFY values were lower than those found by Melo et al. (2010), wherein the maximum value for the cultivar Crimson Sweet was $52,400 \mathrm{~kg} \mathrm{ha}^{-1}$ at a water depth of $266 \mathrm{~mm}$. This difference in yield may be related to genetic characteristics of the cultivars and local edaphoclimatic conditions.

As with MFY, WUE was significantly affected by the water depths $(\mathrm{p}<0.01)$ but not by nitrogen doses and the interaction between these factors (Table 4). These results disagree with those of Mo- rais et al. (2008), who evaluated the response of watermelon plants at different water depths and nitrogen levels in the Curu Valley in Pentecoste, Ceará, Brazil, and found that different water depths and nitrogen doses affected WUE. However, the present results corroborate those of Monteiro et al. (2008) for melon plants in the municipality of Pentecoste, Ceará, who found that the water depths, but not the nitrogen doses, significantly affected WUE.

Table 4. Analysis of variance of the water use efficiency of watermelon at different water depths and nitrogen doses in fertigation.

\begin{tabular}{|c|c|c|c|c|}
\hline Causes of variation & Degrees of freedom & F-value & Probability $>$ F & $\mathrm{R}^{2}$ \\
\hline Water depth (L) & 4 & 4703.54 & 0.00001 & \\
\hline Linear regression & 1 & 17394.92 & 0.00010 & 0.9246 \\
\hline Quadratic regression & 1 & 1295.44 & 0.00010 & 0.9934 \\
\hline Nitrogen $(\mathrm{N})$ & 4 & 0.01 & 0.99950 & \\
\hline Linear regression & 1 & 0.01 & 0.94000 & 0.0971 \\
\hline Quadratic regression & 1 & 0.03 & 0.86200 & 0.6048 \\
\hline Interaction $\mathrm{L} \times \mathrm{N}$ & 16 & 0.01 & 1.00000 & \\
\hline Overall mean & & $16.77 \mathrm{~kg} \mathrm{~m}^{-3}$ & & \\
\hline
\end{tabular}

The maximum WUE $\left(21.11 \quad \mathrm{~kg} \quad \mathrm{~m}^{-3}\right)$ corresponds to the water depth $110.42 \mathrm{~mm}$. WUE decreased with increasing irrigation depths, reaching a decrease of up to $47 \%$ when compared to the highest irrigation depth, $317.09 \mathrm{~mm}$ (Figure 3). This result indicates that the increase in fruit yield up to a water depth of $233.48 \mathrm{~mm}$ was proportionally lower than the water volume added, reducing the efficiency of use of this input. This finding may also be related to the maintenance of the balance between the rates of water absorption and transpiration, which can increase WUE. Furthermore, the number and size of leaves of plants subjected to water stress are reduced to avoid water loss to the atmosphere (TAIZ; ZEIGER, 2009).

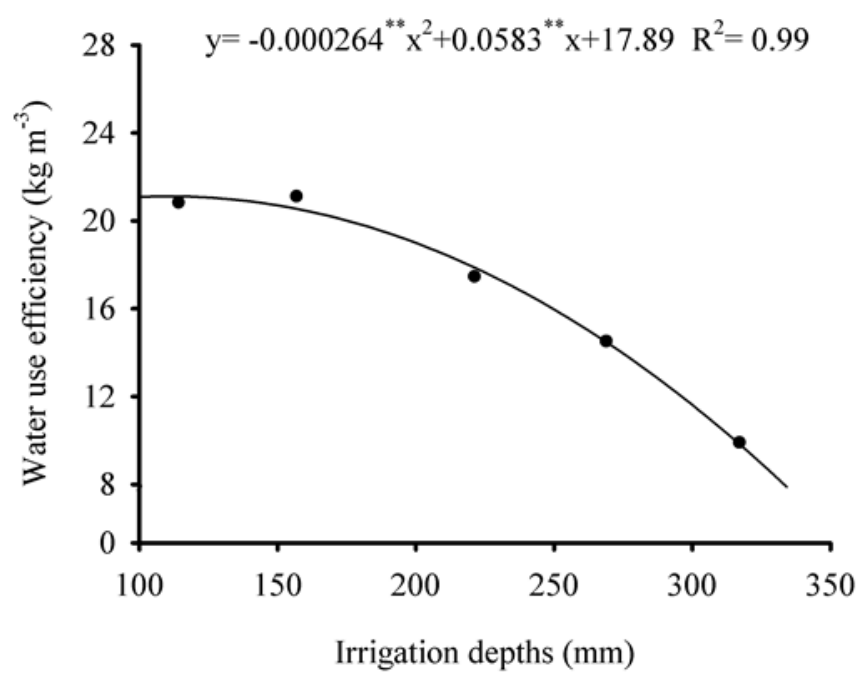

Figure 3. Water use efficiency by watermelon plants at different water depths. ${ }^{* *}$ significant at a level of significance of $1 \%$ using Student's $t$-test.

The low availability of water in the soil reduces the leaf area index as a response to stress. Consequently, water loss via transpiration is reduced, which may significantly increase WUE. However, the rate of production of photoassimilates and fruit growth and yield are reduced.

It was observed a decrease in the number of leaves with the lowest irrigation depth $(110.17 \mathrm{~mm})$, possibly due to the adaptation mechanisms of the plant to water stress, resulting in a decrease in water use efficiency. Taiz and Zeiger (2009) have shown that plants have adaptations to control leaf water loss and restore the water lost to the atmosphere to meet water demands and maximize $\mathrm{CO}_{2}$ absorption. Moreover, when soil water is less abundant, stomata open less or even remain closed under conditions of 
intense sunshine (Figure 1C).

The highest WUE in the Top Gun hybrid was $21.11 \mathrm{~kg} \mathrm{~m}^{-3}$, which was lower than that found by Miranda, Oliveira, and Souza (2004) $\left(21.6 \mathrm{~kg} \mathrm{~m}^{-3}\right)$ and Melo et al. (2010) $\left(23.2 \mathrm{~kg} \mathrm{~m}^{-3}\right)$ for $100 \%$ of the class A evaporation pan (CAE) and $130 \%$ of the ETo, respectively, in the cultivar Crimson Sweet under drip irrigation. Morais et al. (2008) observed that the highest WUE in the cultivar Charleston Gray was $24.21 \mathrm{~kg} \mathrm{~m}^{-3}$ for $50 \%$ of the CAE. These results suggest that the differences in WUE at different water depths depend, among other factors, on the cultivated area and local edaphoclimatic conditions.

The WUE values corroborate those found by Monteiro et al. (2008), who evaluated WUE and
NUE in melon crops in Pentecoste, Ceará, at the water depths of 232.7, 334.7, 422.1, and $567.8 \mathrm{~mm}$ and nitrogen doses of $0,75,150$, and $300 \mathrm{~kg} \mathrm{ha}^{-1}$, and found that WUE decreased as the water depths increased but was not significantly affected by nitrogen. Moreover, WUE was highest using 232.7 $\mathrm{mm}$ of water. Oliveira et al. (2012) have shown that crops with high WUE are useful for saving water resources, allowing higher yields per $\mathrm{m}^{3}$ of irrigation water.

In contrast to MFY and WUE, NUE was affected by the water depths and nitrogen doses separately $(p<0.01)$ and by the interaction between these two sources of variation $(p<0.01)$ (Table 5).

Table 5. Analysis of variance of nitrogen use efficiency of watermelon at different water depths and nitrogen doses in fertigation.

\begin{tabular}{ccccc}
\hline Causes of variation & Degrees of freedom & F-value & Probability $>\mathrm{F}$ & $\mathrm{R}^{2}$ \\
\hline Water depth $(\mathrm{L})$ & 4 & 2576.35 & 0.00001 & \\
Linear regression & 1 & 2984.09 & 0.00010 & 0.2896 \\
Quadratic regression & 1 & 7209.95 & 0.00010 & 0.9892 \\
Nitrogen (N) & 3 & 8299.10 & 0.00001 & \\
Linear regression & 1 & 21472.77 & 0.00010 & 0.8625 \\
Quadratic regression & 1 & 3186.41 & 0.00010 & 0.9904 \\
Interaction L $\times$ N & 12 & 173.64 & 0.00001 & \\
\hline Overall mean & $99.07 \mathrm{~kg} \mathrm{~kg}^{-1}$ \\
\hline
\end{tabular}

These results disagree with those of Monteiro et al. (2008), who assessed the response of melon plants to different water depths and nitrogen doses in Pentecoste, Ceará, and found that these parameters did not significantly affect NUE.

NUE was influenced by the interaction between the factors. NUE increased as the water depth increased up to a certain level and decreased as the nitrogen doses increased. The highest NUE was $250.58 \mathrm{~kg} \mathrm{~kg}^{-1}$ using $232.21 \mathrm{~mm}$ of water and $50 \mathrm{~kg}$ $\mathrm{ha}^{-1}$ of nitrogen (Figure 4). Similar results were obtained for irrigated rice (FAGERIA; SANTOS; CUTRIM, 2009) and common beans (SANT'ANA; SANTOS; SILVEIRA, 2011).

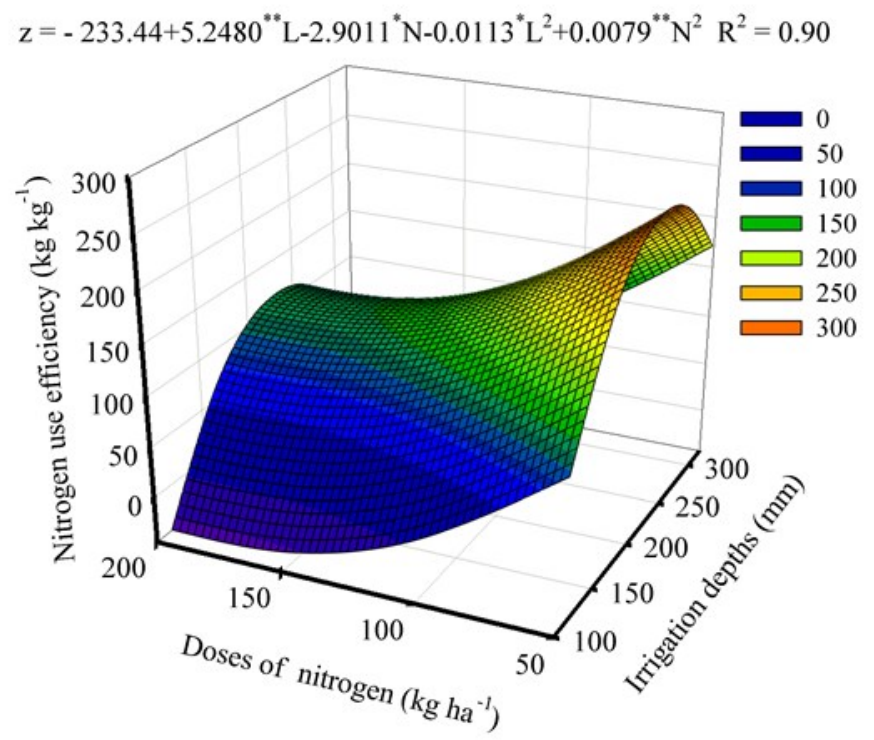

Figure 4. Response surface analysis of nitrogen use efficiency of watermelon as a function of the interaction between water depths and nitrogen doses in fertigation. *and **significant at a level of 5\% and $1 \%$ using Student's $t$-test, respectively. 
Water availability increased NUE up to a water depth of $232.21 \mathrm{~mm}$ and decreased starting at that depth, in contrast to the nitrogen doses used in fertigation, which may have increased nutrient loss by leaching, especially at higher nitrogen doses. Given the high concentration of $\mathrm{NO}_{3}{ }^{-}$in soils of sandy texture (Table 1), there is a predominance of negative electrical charges in the arable layer because of high oxygen availability, making $\mathrm{NO}_{3}{ }^{-}$ adsorption negligible. The increase in negative charges may contribute to nitrate leaching in deeper layers of the soil, limiting the absorption of this anion by the root system of the crops, especially in conditions of high availability of water and nitrogen (PIOVESAN et al., 2009; ARAGÃO et al., 2012; LUNA et al., 2013).

These results differ from those obtained by Monteiro et al. (2008) in melon plants at different water depths and nitrogen doses, wherein isolated or interacting factors did not significantly affect NUE. However, these authors observed that NUE tended to increase as nitrogen doses decreased up to $150 \mathrm{~kg} \mathrm{ha}$ 1 and decreased at $300 \mathrm{~kg} \mathrm{ha}^{-1}$ of nitrogen. The highest NUE value $\left(75.54 \mathrm{~kg} \mathrm{~kg}^{-1}\right)$ was obtained using $75 \mathrm{~kg} \mathrm{ha}^{-1}$ of nitrogen and $334.7 \mathrm{~mm}$ of water.

\section{CONCLUSIONS}

Watermelon fruit yield was highest at a water depth of $233.48 \mathrm{~mm}$.

The highest WUE was obtained at a water depth of $110.42 \mathrm{~mm}$.

The highest NUE was obtained using 232.21 $\mathrm{mm}$ of water and $50 \mathrm{~kg} \mathrm{ha}^{-1}$ of nitrogen.

\section{REFERENCES}

ALLEN, R. G.et al. Crop evapotranspiration: Guidelines for computing crop water requirements. Rome: FAO, 1998. 300 p. (FAO Irrigation and Drainage Paper, 56).

ANDRADE JÚNIOR, A. S. et al. Produção e qualidade de frutos de melancia à aplicação de nitrogênio via fertirrigação. Revista Brasileira de Engenharia Agrícola e Ambiental, v. 10, n. 4, p. 836-841, 2006.

ANDRADE JUNIOR, A. S. et al. Frequência de aplicação de nitrogênio e de potássio via água de irrigação por gotejamento na cultura da Melancia em Parnaíba, PI. ACSA - Agropecuária Científica no Semi-Árido, v. 3, n. 1, p. 1-7, 2007.

AQUINO, A. B. et al. Recomendações de adubação e calagem para o Estado do CE. 1. ed. Fortaleza, CE: UFC, 1993. 247 p.
ARAGÃO, V. F. et al. Produção e eficiência no uso de água do pimentão submetido a diferentes lâminas de irrigação e níveis de nitrogênio. Revista Brasileira de Agricultura Irrigada, v. 6, n. 3, p. 207-216, 2012.

ARAÚJO, W. F. et al. Crescimento e produção de melancia submetida a doses de Nitrogênio. Revista Caatinga, v. 24, n. 4, p. 80-85, 2011.

COSTA, G. F.; MARENCO, R. A. Fotossíntese, condutância estomática e potencial hídrico foliar em árvores jovens de andiroba (Carapa guianensis). Acta Amazonica, v. 37, n. 2, p. 229-234, 2007.

DOORENBOS, J.; KASSAN, A. H. Efeito da água no rendimento das culturas. Campina Grande: UFPB, 1994. 306 p. (FAO. Estudos FAO. Irrigação e Drenagem, 33).

FAGERIA, N. K.; SANTOS, A. B.; CUTRIM, V. A. Nitrogen uptake and its association with grain yield in lowland rice genotypes. Journal of Plant Nutrition, v. 32, n. 11, p. 1965-1974, 2009.

FERREIRA, J. O. P. Evapotranspiração e coeficientes de cultura da melancieira irrigada por gotejamento em Alvorada do Gurguéia-PI. 2010. 121 f. Tese (Doutorado em Agronomia: Área de Concentração em Produção Vegetal) Universidade Estadual Paulista, Jaboticabal, 2010.

FERREIRA, J. O. P.; PAVANI, L. C.; BASTOS, E. A. Coeficientes de cultura para a melancieira irrigada por gotejamento no Vale do Gurgueia, PI. Irriga, v. 18 , n. 3, p. 509-521, 2013.

KELLER, J.; BLIESNER, R. D. Sprinkle and trickle irrigation. New York, USA: VAN NOSTRAND REINHOLD, 1990. 652 p.

LUNA, N. R. S. et al. Dinâmica do nitrato e cloreto no solo e a qualidade das águas subterrâneas do distrito de irrigação Baixo Acaraú, CE. Revista Agro@mbiente On-line, v. 7, n. 1, p. 53-62, 2013.

MELO, A. S. et al. Crescimento vegetativo, resistência estomática, eficiência fotossintética e rendimento do fruto da melancieira em diferentes níveis de água. Acta Scientiarum. Agronomy, v. 32, n. 1, p. 73-79, 2010.

MIRANDA, F. R.; OLIVEIRA, J. J. G.; SOUZA, F. Evapotranspiração máxima e coeficientes de cultivo para a cultura da melancia irrigada por gotejamento. Revista Ciência Agronômica, v. 35, n. 1, p. 36-43, 2004

MONTEIRO, R. O. C. et al. Eficiência do uso da água e nitrogênio na produção de melão. Irriga, v. 
13, n. 3, p. 367-377, 2008.

MORAIS, N. B. et al. Resposta de plantas de melancia cultivadas sob diferentes níveis de água e de nitrogênio. Revista Ciência Agronômica, v. 39, n. 3, p. 369-377, 2008.

OLIVEIRA, P. G. F. et al. Eficiência de uso dos fatores de produção água e potássio na cultura da melancia irrigada com água de reuso. Revista Brasileira de Engenharia Agrícola e Ambiental, v. 16, n. 2, p. 153-158, 2012.

PIOVESAN, R. P. et al. Perdas de nutrientes via subsuperfície em colunas de solo sob fertilização mineral e orgânica. Revista Brasileira de Ciência do Solo, v. 33, n. 4, p. 757-766, 2009.

SANT'ANA, E. V. P.; SANTOS, A. B.; SILVEIRA, P. M. Eficiência de uso do nitrogênio em cobertura pelo feijoeiro irrigado. Revista Brasileira de Engenharia Agrícola e ambiental, v. 15, n. 5, p. 458-462, 2011.

SILVA, M. V. T. et al. Eficiência agronômica e fisiológica na melancia fertirrigada com diferentes doses de nitrogênio e fósforo. Revista Verde de agroecologia e desenvolvimento sustentável, v. 9, n. 2 , p. 264-269, 2014.

SOUSA, A. E. C. et al. Produtividade do meloeiro sob lâmina de irrigação e adubação potássica. Engenharia Agrícola, v. 30, n. 2, p. 271-278, 2010.

TAIZ, L.; ZEIGER, E. Fisiologia vegetal. 4 ed. Porto Alegre, RS: ARTMED, 2009. 819 p.

VIANA, T. V. A. et al. Estudo da aptidão agroclimática do Estado do Piauí para o cultivo da aceroleira. Ciência Agronômica, v. 33, n. 2, p. 5-12, 2002. 